\title{
Pengaruh Bangkitan Pergerakan di Koridor Mulyosari terhadap Kinerja Jalannya
}

\author{
Khairunnisa' Qurratu'ain dan Sardjito \\ Departemen Perencanaan Wilayah dan Kota, Instutitut Teknologi Sepuluh Nopember (ITS) \\ e-mail: sardjito24@yahoo.com
}

\begin{abstract}
Abstrak-Kebijakan arah pengembangan kawasan mulyosari adalah sebagai salah satu pusat lingkungan di Unit Pengembangan Kertajaya. Penetapan sebagai Pusat Lingkungan tersebut memberikan frekuensi terjadinya perubahan penggunaan lahan dari non-komersial (perumahan) menjadi komersial (perdagangan dan jasa) dan saat ini sedang mengalami proses ke arah tersebut terutama pada Koridor Jalan Mulyosari. Perubahan penggunaan lahan tersebut memunculkan banyaknya kegiatan-kegiatan perdagangan jasa seperti tempat print, café, warung makan, bengkel, dan salon. Jenis kegiatan tersebut dapat membangkitkan lalu lintas yang dapat mempengaruhi kinerja jalan Mulyosari dan mengakibatkan volume lalu lintas akan meningkat. Penelitian ini bertujuan untuk mengukur pengaruh bangkitan pergerakan di Koridor Jalan Mulyosari terhadap kinerja jalannya. Untuk mencapai tujuan tersebut, dilakukan dua tahapan yaitu menganalisis tingkat pelayanan jalan koridor Jalan Mulyosari Surabaya dengan teknik analisis deskriptif kuantitatif dengan rumus $\mathrm{I}=\mathrm{V} / \mathrm{C}$ dan menganalisis pengaruh volume bangkitan pergerakan dari kegiatan penggunaan lahan di koridor Jalan Mulyosari Surabaya terhadap tingkat pelayanan jalan Mulyosari dengan teknik analisis deskriptif kuantitatif dengan menghitung I kendaraan melintas, I bangkitan, dan I ideal. Berdasarkan hasil analisis, pengaruh bangkitan pergerakan dari penggunaan lahan terhadap kinerja jalan di koridor Jalan Mulyosari, (ideal) sebagai berikut: Untuk Koridor Barat, segmen I : 11,65 \%, seg:men II : 27,39 \% dan segmen III : 5,02 $\%$. Untuk Koridor Timur, segmen I : 12,61 \%, segmen II : 10,09 $\%$ dan segmen III : $15,48 \%$.
\end{abstract}

Kata Kunci-Perubahan Jenis Kegiatan, Kinerja Jalan, Bangkitan Pergerakan.

\section{PENDAHULUAN}

$\mathrm{T}$ RANSPORTASI merupakan urat nadi kehidupan politik, ekonomi, social-budaya dan pertahanan-keamanan yang sangat vital peranannya dalam memperkokoh ketahanan nasional menurut Peraturan Menteri Hubungan No. 49 Tahun 2005 tentang Sistem Transportasi Nasional. Dalam memenuhi kebutuhan, manusia melakukan perjalanan antara tata guna lahan satu dengan tata guna lahan yang lain dengan menggunakan system jaringan transportasi. Hal ini menyebabkan timbulnya pergerakan [1].

Pengaruh bangkitan pergerakan tidak hanya datang dari jenis kegiatannya saja, tetapi juga jumlah dan luas lantai yang dipakai untuk kegiatan tersebut. Bangkitan pergerakan tidak hanya ditinjau dari ragam jenis tata guna lahan, tetapi juga tingkat aktivitasnya [2]. Semakin tinggi intensitas penggunaan sebidang tanah, semakin tinggi pergerakan arus lalu lintas yang dihasilkannya.

Sistem yang berhubungan dengan tata guna lahan adalah sistem kegiatan. Sistem kegiatan memiliki tipe kegiatan tertentu yang akan membangkitan pergerakan (trip production) dan akan menarik pergerakan (traffic atraction) [1]. Sistem tersebut merupakan suatu sistem pola kegiatan tata guna lahan yang terdiri dari system pola kegiatan social, ekonomi, kebudayaan dan lain-lain. Kegiatan yang timbul dalam sistem ini membutuhkan adanya pergerakan sebagai alat pemenuhan yang perlu dilakukan setiap hari.

Salah satu kawasan di Kota Surabaya yang mengalami perubahan guna lahan yang cepat, adalah di Kawasan Jalan Mulyosari. Adanya berbagai kegiatan yang dimiliki koridor Jalan Mulyosari, maka setiap harinya kegiatan-kegiatan di sepanjang sisi Jalan Mulyosari menghasilkan sirkulasi manusia maupun barang secara terus menerus baik pagi, siang, sore maupun malam hari.

Kebijakan arah pengembangan kawasan Mulyosari adalah sebagai salah satu pusat lingkungan di Unit Pengembangan Kertajaya. Penetapan sebagai pusat tersebut memberikan konsekuensi terjadinya perubahan pemanfaatan ruang dari non-komersial (perumahan) menjadi komersial (perdagangan dan jasa) dan saat ini sedang mengalami proses ke arah tersebut. Perubahan pemanfaatan lahan tersebut memuncul kan banyaknya kegiatan-kegiatan perdagangan jasa seperti tempat print, café, warung makan, bengkel, dan salon. Jenis kegiatan tersebut dapat membangkitkan lalu lintas yang dapat mempe ngaruhi kinerja jalan Mulyosari dan mengakibatkan volume lalu lintas akan meningkat. Dari permasalahn tersebut, maka rumusan pertanyaan penelitian adalah "Bagaimana pengaruh bangkitan pergerakan terhadap kinerja Jalan Mulyosari di koridor Jalan Mulyosari?"

\section{METODE PENELITAN}

\section{A. Pendekatan dan Jenis Penelitian}

Pendekatan yang digunakan dalam penelitian ini adalah pendekatan positivistic yang bersumber pada fakta empiri dimana ilmu yang dibangun berasal dari hasil pengamatan indera dengan didukung landasan teori [3].

\section{B. Variabel Penelitian}

Variabel penelitian yang digunakan untuk menganilisis tingkat pelayanan jalan koridor Jalan Mulyosari antara lain jenis kendaraan, jumlah kendaraan, geometrik jalan, lebar efektif jalan, pembagian arah, gangguan samping dan ukuran kota, sedangkan untuk menganalisis pengaruh volume bangkitan bangkitan pergerakan dari kegiatan penggunaan lahan di koridor Jalan Mulyosari Surabaya terhadap tingkat pelayanan jalan Mulyosari menggunakan variabel jenis kegiatan penggunaan lahan, angka bangkitan, dan luas lantai kegiatan.

\section{Metode Pengumpulan Data}

Proses pengumpulan data dilakukan dengan cara survei primer dan sekunder. Metode untuk pengumpulan data primer adalah survey perhitungan kendaraan (Traffic Counting), sensus penggunaan lahan dan survey penampang jalan. Sedangkan metode untuk pengumpulan data sekunder dalam penelitian ini meliputi survei literatur. 


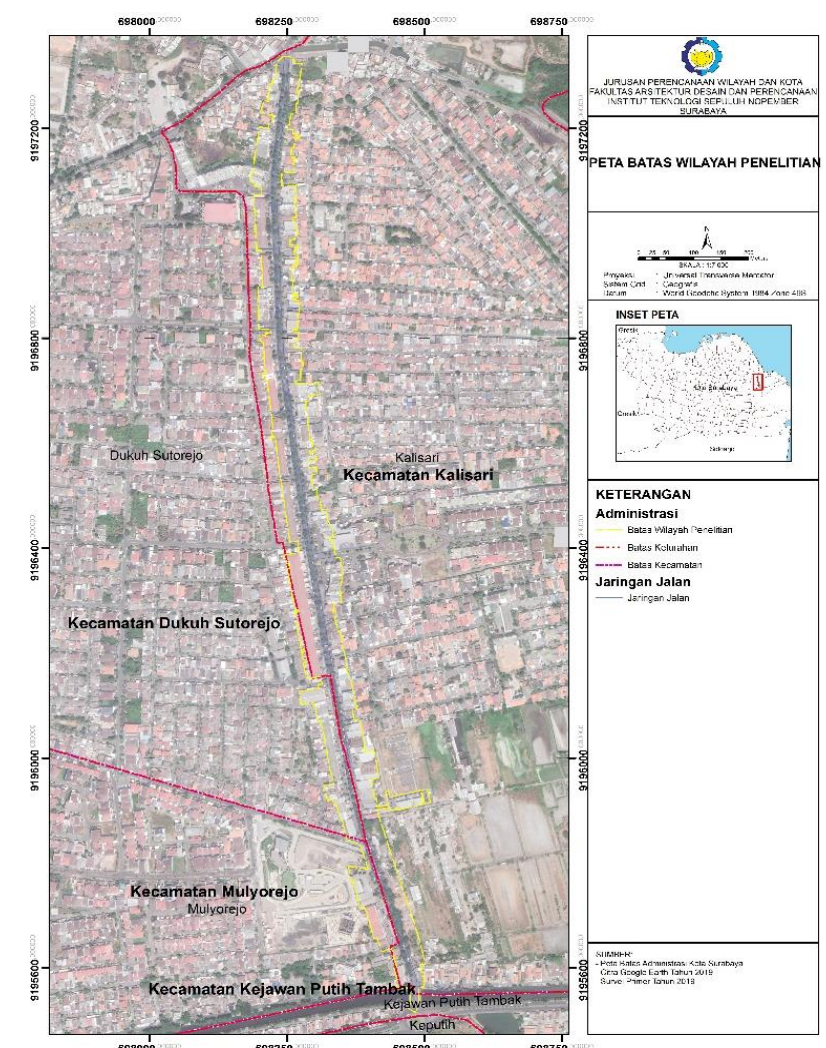

Gambar 1. Batas Wilayah Penelitian.

\section{Metode Analisis}

1) Menganalisis Tingkat Pelayanan Jalan Koridor Jalan Mulyosari Surbaya

Intensitas pelayanan jalan merupakan angka intensitas yang menunjukan tingkat kemampuan suatu jalan. Dalam perumus sannya, intensitas jalan adalah perbandingan antara volume lalu lintas dengan kapasitas jalan yang ada, seperti rumus berikut:

Dimana:

$$
\mathrm{I}=\frac{\mathrm{V}}{\mathrm{C}}
$$

I : Intensitas Pelayanan Jalan

V : Volume Lalu Lintas (smp/jam)

C : Kapasitas (smp/jam)

Untuk menentukan kapasitas jalan dilihat dari standar yang telah ditetapkan oleh Manual Kapasitas Jalan Indonesia dapat ditentukan menggunakan rumus sebagai berikut :

$$
\mathrm{C}=\mathrm{C}_{0} \times \mathrm{FC}_{\mathrm{W}} \times \mathrm{FC}_{\mathrm{SP}} \times \mathrm{FC}_{\mathrm{SF}} \times \mathrm{FC}_{\mathrm{CS}}
$$

Dimana :

$\mathrm{C}$ : Kapasitas sesungguhnya ( $\mathrm{smp} / \mathrm{jam})$

$\mathrm{C}_{0}$ : Kapasitas dasar untuk kondisi tertentu (ideal) (smp/jam)

$\mathrm{FC}_{\mathrm{W}}$ : Faktor penyesuaian lebar jalan

$\mathrm{FC}_{\mathrm{SP}}$ : Faktor penyesuaian pemisahan arah

$\mathrm{FC}_{\mathrm{SF}}$ : Faktor penyesuaian hambatan samping

FC $_{\mathrm{CS}}$ : Faktor penyesuaian ukuran kota

2) Menganalisis Pengaruh Volume Bangkitan Pergerakan Dari Kegiatan Penggunaan Lahan Di Koridor Jalan Mulyosari Surabaya Terhadap Tingkat Pelayanan Jalan Mulyosari

a. Mengukur Volume Bangkitan Pergerakan yang Ditimbulkan oleh Kegiatan-Kegiatan di Koridor Mulyosari

Dalam menghitung volume bangkitan pergerakan akan menggunakan analisis kuantitatif. Volume bangkitan
Tabel 1.

\begin{tabular}{|c|c|c|c|c|c|}
\hline 总 & 宓 & $\underset{\Xi}{\Xi}$ & 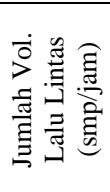 & 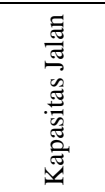 & 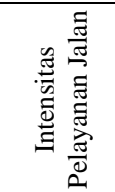 \\
\hline 1 & Utara & $16.00-17.00$ & 1949,17 & 3033,27 & 0,642597 \\
\hline 2 & Utara & $16.00-17.00$ & 1744,47 & 3033,27 & 0,575112 \\
\hline 3 & Utara & $16.00-17.00$ & 1875,08 & 3033,27 & 0,618171 \\
\hline 4 & Utara & $16.00-17.00$ & 1719,74 & 3033,27 & 0,566959 \\
\hline 5 & Utara & $16.00-17.00$ & 1680,66 & 3033,27 & 0,554075 \\
\hline 6 & Utara & $16.00-17.00$ & 1486,23 & 3033,27 & 0,489976 \\
\hline 7 & Selatan & $16.00-17.00$ & 1887,3 & 3033,27 & 0,6222 \\
\hline 8 & Selatan & $16.00-17.00$ & 1824,6 & 3033,27 & 0,601529 \\
\hline 9 & Selatan & $16.00-17.00$ & 1983,79 & 3033,27 & 0,65401 \\
\hline 10 & Selatan & $16.00-17.00$ & 1945,72 & 3033,27 & 0,64146 \\
\hline 11 & Selatan & $16.00-17.00$ & 1901,29 & 3033,27 & 0,626812 \\
\hline 12 & Selatan & $16.00-17.00$ & 1891,88 & 3033,27 & 0,62371 \\
\hline
\end{tabular}

Intensitas Pelayanan Jalan

Tabel 2.

Standar Bangkitan Pergerakan yang Digunakan dalam Penelitian

\begin{tabular}{ccc}
\hline \hline & Sumber & $\begin{array}{c}\text { Angka Bangkitan } \\
\text { (Smp/jam/100m2) }\end{array}$ \\
\hline \multirow{6}{*}{ Minimarket } & 10,59 \\
Bangunan & kosong \\
Penis & Perkantoran & 0 \\
Kegiatan & Perumahan & 1 \\
& Rumah makan & 1,45 \\
& Bisnis/jasa & 0,39 \\
& lainnya & 5,35 \\
& Bengkel & 2,87 \\
& Fasilitas umum & 1,92 \\
& Pasar swalayan & 3,37 \\
& Restoran Siap & 2,05 \\
Saji & 5,95 \\
& Restoran & 0,60 \\
\hline \hline
\end{tabular}

pergerakan didapatkan dengan perkalian antara luas lahan dengan tingkat bangkitan yang ditimbulkan oleh suatu jenis kegiatan dalam satuan volume kendaraan per jam (smp/jam) dengan rumus:

Besaran bangkitan pergerakan $=\frac{\text { luas lantai } \times \text { standar bangkitan }}{100}$

Perhitungan volume bangkitan pergerakan ini dilakukan pada setiap jenis kegiatan, sehingga akan diketahui besaran volume bangkitan dan tarikan pada setiap jenis kegiatan. Data mengenai luas lantai kegiatan didapatkan melalui pengamatan secara langsung terhadap masing-masing jenis kegiatan. Kemudian untuk masing-masing jenis kegiatan memiliki standar bangkitan yang berbeda pula.

b. Mengukur pengaruh volume bangkitan - tarikan pergerakan jenis kegiatan terhadap kinerja ruas jalan Mulyosari

Untuk mengetahui pengaruh bangkitan pergerakan dilakukan analisis deskriptif kuantitatif yang menggunakan rumus perhitungan intensitas jalan eksisting, dimana volume yang digunakan adalah selisih dari volume yang masuk dengan volume yang keluar (diasumsikan bahwa selisih volume masuk dan keluar adalah volume yang berinteraksi atau berhenti pada kawasan) yang ditambahkan dengan volume yang melintas. Dari hasil perhitungan tersebut dibandingkan dengan hasil perhitungan intensitas ideal ketika kegiatan di kawasan tersebut berfungsi secara optimal.

Berikut merupakan perhitungan pengaruh volume bangkitan pergerakan dari kegiatan penggunaan lahan terhadap intensitas pelayanan jalan [4]: 
Tabel 3.

Intensitas Bangkitan Pergerakan Koridor Jalan Mulyosari Surabaya

\begin{tabular}{llcrc}
\hline \hline \multicolumn{1}{c}{ Pembagian Segmen } & \multicolumn{2}{c}{ Volume Bangkitan } & Kapasitas Jalan & Intensitas Bangkitan \\
\hline & & Koridor Barat & 3033,27 & 0,093 \\
Segmen I & $282,8 \mathrm{smp} / \mathrm{jam}$ & & 3033,27 & 0,219 \\
Segmen II & $664,63 \mathrm{smp} / \mathrm{jam}$ & & 3033,27 & 0,040 \\
Segmen III & $121,7 \mathrm{smp} / \mathrm{jam}$ & & & \\
& & & 3033,27 & 0,101 \\
Segmen I & $306 \mathrm{smp} / \mathrm{jam}$ & & 3033,27 & 0,081 \\
Segmen II & $244,91 \mathrm{smp} / \mathrm{jam}$ & & 3033,27 & 0,124 \\
Segmen III & $375,66 \mathrm{smp} / \mathrm{jam}$ & & & \\
\hline \hline
\end{tabular}

Tabel 4.

Pengaruh Angka Bangkitan Pergerakan dari Penggunaan Lahan Terhadap Kinerja Jalan Ideal di Koridor Barat Jalan Mulyosari

\begin{tabular}{ccccc}
\hline \hline \multirow{2}{*}{ Pembagian Segmen } & $\begin{array}{c}\text { Pengaruh Bangkitan Pergerakan } \\
\text { dari Penggunaan Lahan (Eksisting) }\end{array}$ & Kondisi Ideal & $\begin{array}{c}\text { Selisih Kondisi Ideal - } \\
\text { Eksisting }\end{array}$ & $\begin{array}{c}\text { Besaran Pengembangan } \\
\text { (smp/jam) }\end{array}$ \\
\hline Segmen I & 0,668 & 0,8 & 0,132 & 400,39 \\
Segmen II & 0,786 & 0,8 & 0,014 & 42,47 \\
Segmen III & 0,53 & 0,8 & 0,27 & 818,98 \\
\hline \hline
\end{tabular}

I Melintas = Volume melintas/kapasitas

I Bangkitan = Volume bangkitan/ kapasitas

I Pengaruh = I Melintas + I Bangkitan

Besaran pengaruh bangkitan $=\mathrm{I}$ Pengaruh $-0,8$

\section{HASIL DAN PEMBAHASAN}

\section{A. Wilayah Penelitian}

Wilayah yang digunakan pada penelitian ini terletak di Jalan Raya Mulyosari. Wilayah Koridor Jalan Raya Mulyosari secara administrasi ada di Kelurahan Kalisari Kecamatan Mulyorejo, Kota Surabaya. Dalam penelitian ini, fokus wilayah studi adalah di Koridor Jalan Mulyosari. "Koridor Jalan" yang dimaksud dalam penelitian ini adalah ruang kegiatan yang berkaitan langsung dengan Jalan Mulyosari, pergerakan keluar-masuknya ke ruang kegiatan melalui Jalan Mulyosari. Wilayah penelitian tersebut dapat dilihat pada Gambar 1.

\section{B. Analisis Tingkat Pelayanan Jalan}

Tingkat pelayanan jalan pada jalan perkotaan dapat diketahui dari intensitas pelayanan jalan, dimana intensitas pelayanan jalan dihitung menggunakan rumus sebagai berikut:

$$
\mathrm{I}=\frac{\mathrm{V}}{\mathrm{C}}
$$

I : Tingkat Pelayanan Jalan (Intensitas Pelayanan Jalan)

$\mathrm{V}:$ Volume kendaraan melintas

$\mathrm{C}$ : Kapasitas jalan

Berdasarkan hasil perhitungan volume lalu lintas pada waktu peak hour dan hasil perhitungan kapasitas jalan maka dapat dilakukan perhitungan intensitas pelayanan jalan di setiap titik perhitungan lalu lintas. (Tabel 1). Berdasarkan hasil perhitungan pada Tabel 1, bahwa setiap segmen dengan adanya karakteristik jalan yang berbeda-beda akan mempengaruhi tingkat pelayanan jalan yang ada, dan dapat disimpulkan bahwa berdasar tingkat pelayanan jalan yang ada di Jalan Mulyosari tidak/belum memiliki nilai intensitas $\geq$ 0,8 , hal tersebut menjadikan Jalan Mulyosari belum terdapat masalah lalu lintas, karena pada dasarnya Menurut MKJI (1997) dalam Charky, L (2015), apabila suatu ruas jalan memiliki nilai intensitas $\geq 0,8$ maka pada ruas jalan tersebut terjadi arus tidak stabil, sering berhenti, dan volume lalu lintas mendekati atau berada pada kapasitas jalan.

Untuk mengetahui besaran dari Trip Attraction dan Trough Traffic yang ada, dilakukan dengan cara sebagai berikut: a. Trip Attraction: Dapat diketahui dengan cara mencari selisih antara intensitas yang saling berhubungan di masing-masing segmen (sesuai karakteristik jalan);

b. Trough Traffic: Dapat diketahui dengan cara melihat hasil dari intensitas yang berada di titik perhitungan lalu lintas terkahir dari masing-masing segmen (sesuai karakteristik jalan).

Traffic Atraction

Koridor Barat

Segmen I

Segmen II

Segmen III

Koridor Timur

Segmen I

Segmen II

Segmen III

Through Traffic

Koridor Barat

Segmen I

Segmen II

Segmen III

Koridor Timur

Segmen I

Segmen II

Segmen III
: I titik 1 - I titik 2

: I titik 3 - I titik 4

: I titik 5 - I titik 6

: I titik 11 - I titik 12

: I titik $9-$ I titik 10

: I titik 7 - I titik 8

$: 0,1255$

: 0,00207

: I titik 1 - I titik 2

: I titik 3 - I titik 4

$: 0,575$

: I titik 5 - I titik 6

: 0,567

: 0,49

: I titik 11 - I titik 12

: 0,624

: I titik 9 - I titik 10

: 0,641

: I titik 7 - I titik 8

: 0,601
C. Analisis Pengaruh Volume Bangkitan Pergerakan dari Kegiatan Penggunaan Lahan di Koridor Jalan Mulyosari Surabaya Terhadap Tingkat Pelayanan Jalan Mulyosari

1) Mengukur Volume Bangkitan Pergerakan yang Ditimbulkan Oleh Kegiatan-Kegiatan Di Koridor Mulyosari Karakteristik Koridor Jalan Mulyosari merupakan jalan Lintasn, belum menjadi kawasan tujuan pergerakan (pemenuhan kebutuhan barang dan jasa), dalam skala Unit Pengembangan Kertajaya merupakan pusat pengembangan lingkungan (PPL), maka angka bangkitan pergerakan yang dapat diterapkan (merupakan kombinasi standart angka bangkitan yang telah ada) untuk wilayah penelitian ditunjukkan pada Tabel 2:

Berdasarkan hasil identifikasi kegiatan penggunaan lahan di kawasan penelitian menurut jenis dan luas lantai tiap jenis kegiatan di kawasan penelitian, kemudian dengan mengalikan angka bangkitan tiap jenis kegiatan yang sesuai, maka dapat dihitung volume bangkitan dari tiap jenis kegiatan di koridor Jalan Mulyosari. Untuk melakukan perhitungan volume bangkitan pergerakan (smp) yang ada 
Tabel 5 .

Pengaruh Angka Bangkitan Pergerakan dari Penggunaan Lahan Terhadap Kinerja Jalan Ideal di Koridor Timur Jalan Mulyosari

\begin{tabular}{ccccc}
\hline \hline Pembagian Segmen & $\begin{array}{c}\text { Pengaruh Bangkitan Pergerakan } \\
\text { dari Penggunaan Lahan (Eksisting) }\end{array}$ & Kondisi Ideal & $\begin{array}{c}\text { Selisih Kondisi Ideal - } \\
\text { Eksisting }\end{array}$ & $\begin{array}{c}\text { Besaran Pengembangan } \\
\text { (smp/jam) }\end{array}$ \\
\hline Segmen I & 0,725 & 0,8 & 0,075 & 227,50 \\
Segmen II & 0,722 & 0,8 & 0,078 & 236,60 \\
Segmen III & 0,725 & 0,8 & 0,075 & 227,50 \\
\hline \hline
\end{tabular}

Tabel 6.

Pengaruh Volume Bangkitan Kegiatan Terhadap Volume Lalu Lintas Ideal Jalan Mulyosari

\begin{tabular}{lccc}
\hline \hline \multicolumn{1}{c}{ Koridor Barat } & $\begin{array}{c}\text { Volume Bangkitan Kegiatan } \\
\text { (Eksisting) }\end{array}$ & $\begin{array}{c}\text { Volume Lalu Lintas } \\
\text { (Ideal) }\end{array}$ & $\begin{array}{c}\text { Prosentase Volume Bangkitan Kegiatan } \\
\text { Eksisting/Ideal }\end{array}$ \\
\hline Segmen I & 282,8 & 2426,616 & 11,65 \\
Segmen II & 664,63 & 2426,616 & 27,39 \\
Segmen III & 121,7 & 2426,616 & 5,02 \\
\hline \hline
\end{tabular}

pada setiap jenis kegiatan menggunakan rumus sebagai berikut:

$$
\text { Besaran bangkitan pergerakan }=\frac{\text { luas lantai } \times \text { standar bangkitan }}{100}
$$

Berdasarkan hasil perhitungan besaran volume bangkitan lalu lintas per segmen di Koridor Jalan Mulyosari dapat disimpulkan besaran bangkitan lalu lintas dari kegiatan yang berlokasi di koridor Jalam Mulyosari Koridor Barat dan Koridor Timur persegmennya adalah sebagai berikut:

Koridor Barat

Segmen I

Segmen II

Segmen III

Koridor Timur

Segmen I

Segmen II

Segmen III

$$
\begin{aligned}
& : 282,8 \mathrm{smp} / \mathrm{jam} \\
& : 664,63 \mathrm{smp} / \mathrm{jam} \\
& : 121,7 \mathrm{smp} / \mathrm{jam}
\end{aligned}
$$

2) Mengukur Pengaruh Volume Bangkitan - Tarikan Pergerakan Jenis Kegiatan Terhadap Kinerja Ruas Jalan Mulyosari

Setelah mengetahui volume bangkitan lalu lintas yang ada di koridor Jalan Mulyosari, maka dapat dilakukan perhitungan mengenai intensitas pelayanan jalan yang diakibatkan oleh volume bangkitan lalu lintas. Perhitungan tersebut digunakan untuk mengetahui besaran dampak yang ditimbulkan dari setiap jenis penggunaan lahan terhadap kinerja jalan. Berikut merupakan perhitungan intensitas pelayanan jalan dari penggunaan lahan di tiap segmen di koridor Jalan Mulyosari:

$$
\mathrm{I}=\frac{\mathrm{V}}{\mathrm{C}}
$$

I : Tingkat Pelayanan Jalan (Intensitas Pelayanan Jalan)

V : Volume Bangkitan Pergerakan Kegiatan

$\mathrm{C}$ : Kapasitas jalan

Hasil dari perhitungan volume bangkitan pergerakan kegiatan di masing-masing segmen, dapat diperhitungkan tingkat pelayanan jalan akibat pembebanan volume bangkitan pergerakan dari kegiatan. Bahwa kapasitas Jalan Mulyosari, berdasarkan hasil perhitungan yang telah dilakukan sebesar 3033,27 smp/jam. Berdasarkan hal tersebut, maka intensitas pelayanan jalan Mulyosari karena pembebanan volume bangkitan kegiatan ditunjukkan pada Tabel 3.

Tingkat pelayanan jalan akibat volume bangkitan kegiatan, dapat dipandang sebagai lalu lintas yang berkepentingan (traffic attraction). Hasil perhitungan intensitas pelayanan jalan berdasarkan volume bangkitan pergerakan (menggunakan dasar angka bangkitan pergerakan) bila dibandingkan dengan intensitas pelayanan jalan dari lalu lintas yang berkepentingan eksisting, menunjukan bahwa lalu lintas yang berkepentingan (traffic attraction) eksisting lebih rendah dibandingkan dengan hasil perhitungan dengan menggunakan angka bangkitan pergerakan. Hal ini dimungkinkan, bahwa kemampuan kegiatan yang ada untuk tiap jenis kegiatan, belum mampu sepenuhnya menarik pergerakan lalu lintas (konsumen).

Apabila tiap jenis kegiatan yang ada sekarang, diassumsikan sudah mampu menarik pergerakan seusai dengan standar angka bangkitan pergerakannya, kemudian bahwa volume lalu lintas yang menerus (through traffic) diasumsikan tetap, maka intensitas pelayanan jalan Mulyosari dapat diperhitungkan sebagai berikut:

Intensitas Pelayanan Jalan yang Melintas

Koridor Barat

Segmen I $: 0,575$

Segmen II $: 0,567$

Segmen III : : 0,49

Koridor Timur

Segmen I $\quad: 0,624$

Segmen II $\quad: 0,641$

Segmen III : : 0,601

Kemudian intensitas pelayanan jalan berdasarkan volume lalu lintas yang melintas di masing-masing segmen, ditambah dengan intensitas pelayanan Jalan Mulyosari karena pembebanan volume bangkitan kegiatan di masing-masing segmen, dapat diproleh gambaran Intensitas Pelayanan Jalan Mulyosari. Berdasarkan hal tersebut, diperoleh gambaran pengaruh volume bangkitan pergerakan dari jenis kegiatan penggunaan lahan Terhadap Kinerja Jalan di koridor Jalan Mulyosari, sebagai berikut:

Koridor Barat

Segmen I : : 0,668

Segmen II : : 0,786

Segmen III : $: 0,53$

Koridor Timur

Segmen I : : 0,725

Segmen II : : 0,722

Segmen III $: 0,725$

Intensitas pelayanan jalan dapat dinilai ideal apabila intensitas $=0,8$. Dengan asumsi jika nilai intensitas pelayanan jalan $<0,8$ maka suatu ruas jalan masih dapat berfungsi secara normal dan jenis kegiatan yang ada dapat ditingkatkan guna mendukung pembangunan kawasan, sedangkan nilai intensitas pelayanan jalan $>0,8$ maka suatu ruas jalan memiliki permasalahan transportasi. Dari hasil perhitungan memberikan gambaran kondisi lalu lintas di Jalan Mulyosari. a. Pada segemen III, pada Koridor Barat dan Segmen I, II dan III di Koridor Timur, kondisi lalu lintasnya arus stabil, tetapi kecepatan dan gerak kendaraan dikendalikan 
Tabel 7.

Pengaruh Volume Bangkitan Kegiatan Terhadap Volume Lalu Lintas Ideal Jalan Mulyosari

\begin{tabular}{cccc}
\hline \hline Koridor Timur & $\begin{array}{c}\text { Volume Bangkitan Kegiatan } \\
\text { (Eksisting) }\end{array}$ & Volume Lalu Lintas (Ideal) & $\begin{array}{c}\text { Prosentase Volume Bangkitan Kegiatan } \\
\text { Eksisting/Ideal }\end{array}$ \\
\hline Segmen I & 306 & 2426,616 & 12,61 \\
Segmen II & 244,91 & 2426,616 & 10,09 \\
Segmen III & 375,66 & 2426,616 & 15,48 \\
\hline \hline
\end{tabular}

b. Pada Segmen I dan segmen II di Koridor Barat arus mendekati stabil, kecepatan masih dapat dikendalikan. V/C masih dapat ditolerir

3) Pengaruh Angka Bangkitan Pergerakan dari Penggunaan Lahan Terhadap Kinerja Jalan Ideal di koridor Jalan Mulyosari

Sebagaimana telah dijelaskan bahwa dengan asumsi jika nilai intensitas pelayanan jalan $<0,8$ maka suatu ruas jalan masih dapat berfungsi secara normal dan jenis kegiatan yang ada dapat ditingkatkan guna mendukung pembangunan kawasan, sedangkan nilai intensitas pelayanan jalan $>0,8$ maka suatu ruas jalan memiliki permasalahan transportasi.

Berdasarkan hasil perhitungan pengaruh bangkitan pergerakan dari penggunaan lahan terhadap kinerja jalan yang kondisinya ideal (Intensitas pelayanan jalan 0.8) di koridor Jalan Mulyosari dapat diketahui besaran pengembangan yang bisa dikembangkan pada Tabel 4 dan Tabel 5. Dari Tabel 6 dan tabel 7 terlihat bahwa prosentase pengaruh valume lalu lintas dari kegiatan yang ada di koridor Jalan Mulyosari terhadap volume lalu lintas idealnya (sesuai dengan kapasitasnya), terbesar pengaruh kegiatannya di segmen Koridor Barat II (27,39 \%), dan terendah di segmen III Koridor Barat (5,02 \%), dengan catatan masih adanya beberapa kaveling bangunan di beberapa segmen koridor. Untuk lebih lengkapmya pengaruh kegiatan di koridor Jalan Mulyosari, terhadap kinerja jalannya dapat dilihat padat Tabel 6 dan Tabel 7.

\section{KESIMPULAN/RINGKASAN}

Berdasarkan hasil analisis pembahasan yang telah dilakukan, maka dapat ditarik kesimpulan dari penelitian ini yaitu :

1. Hasil perhtungan kapasitas Jalan Mulyosari adalah 3033,27 smp/jam.
2. Hasil perhitungan tingkat pelayanan jalan yang dilihat dari intensitas pelayanan jalan:

a. Intensistas lalu lintas yang berinteraksi ke koridor jalan Mulyosari (Traffic Atraction) untuk di Koridor Barat segmen I 0,675, segmen II 0,0052, segmen III 0,064. Untuk Koridor Timur, segmen I 0,0031, segmen II 0,1255 dan segmen III 0,0021.

b. Intensitas lalu lintas menerus (Through Traffic), Untuk Koridor Barat segmen I 0,575, segmen II 0,567 dan segmen III 0,49. Untuk Koridor Timur, segmen I 0,624 , segmen II 0,641 , dan segmen III 0,601

3. Besarnya volume bangkitan lalu lintas akibat adanya kegiatan adalah sebagai berikut:

a. Koridor Barat di segmen I 282,8 smp/jam, segmen II 664,63 smp/jam dan di segmen III 12,7 smp/jam.

b. Koridor Timur di segmen I $306 \mathrm{smp} / \mathrm{jam}$, segmen II 244,91 smp/jam dan di segmen III 375,66 smp/jam.

4. Berdasarkan hal tersebut, diperoleh gambaran Pengaruh Bangkitan Pergerakan dari Penggunaan Lahan Terhadap Kinerja Jalan di koridor Jalan Mulyosari, (ideal) sebagai berikut :

a. Koridor Barat, segmen I 11,65 \%, segmen II 27,39 \% dan segmen III 5,02\%.

b. Koridor Timur, segmen I 12,61 \%, segmen II 10,09\% dan segmen III 15,48\%.

\section{DAFTAR PUSTAKA}

[1] O. Tamin, "Aplikasi Model Perencanaan Transportasi 4 Tahap dalam Pemecahan Transportasi di Negara Sedang Berkembang," J. Tek. Sipil ITB, no. 8, 1994.

[2] O. Tamin, "Penerapan Konsep Interaksi Tata Guna Lahan-Sistem Transportasi," J. Perenc. Wil. dan Kota ITB, vol. 8, no. 3, 1997.

[3] M. Nazir, Metode Penelitian, 5th ed. Jakarta: Ghalia Indonesia, 2003.

[4] H. Darmawan, "Arahan Pengendalian Pemanfaatan Lahan Terhadap Kinerja Jalan Di Koridor Jalan Lingkar Timur Sidoarjo, Kabupaten Sidoarjo," Surabaya, 2016. 